\title{
Research Article \\ REACTION OF DIFFERENT RICE LINES AGAINST LEAF AND NECK BLAST UNDER FIELD CONDITION OF CHITWAN VALLEY
}

\author{
K. D. Puri, S. M. Shrestha, K. D. Joshi and G. B. KC \\ Institute of Agriculture and Animal Sciences, Rampur, Chitwan, Nepal
}

\begin{abstract}
The severity of the rice blast disease (Pyricularia grisea) of both leaf and neck varies with different environment and it becomes destructive under favorable condition. The leaf and neck blast resistance and susceptible interaction of 30 different tropical rice lines were evaluated under low-, mid- and up-land conditions of Chitwan district and classified on the basis of disease severity with respect to susceptible check, Masuli. Of them, 5, 10, 12 and 3 rice lines were resistant to leaf blast, moderately resistant, moderately susceptible susceptible, respectively. Similarly, for the neck blast nine lines were resistant, thirteen moderately resistant, seven moderately susceptible and one was susceptible. The progenies from Masuli/MT4 had the highest leaf and neck blast susceptible reaction, while the most of progenies from IPB (Irradiated Pusa Basmati), KalinghaIII_IR64, Radha 32_KIII and Masuli_IR64 were resistant, and the most promising sources against leaf and neck blast resistance. Therefore, the progenies from these parents can be used in breeding the resistant variety.
\end{abstract}

Key words: Pyricularia grisea, resistance, rice lines

\section{INTRODUCTION}

Rice blast is the most common and destructive disease in irrigated rice of both temperate and subtropical areas of East Asia (Bonman et al., 1991). The disease attacks on leaves, stem nodes, all parts of the panicle and grains (Chin, 1974). The disease was divided into leaf and panicle pathosystem (Teng et al., 1991). Plants got the highest disease at maximum tillering stage then gradually declined, mainly due to adult plant resistance (Yeh and Bonman, 1886; Koh et al., 1987). Then after it infects in panicle and neck node. Although leaf infection is sometimes found at the reproductive and ripening stages, the destructive symptoms during these stages is neck blast, characterized by infection at panicle base (Bonman et al., 1991). Blast epidemic causes complete loss of seedling (Chaudary et al., 1994) in nursery and epidemics in the field (Teng et al., 1991).

In Nepal, the disease causes the 10-20\% yield reduction in susceptible varieties, but in severs case it goes up to $80 \%$ yield reduction (Manandhar et al., 1992). Panicle infection causes complete yield loss (Ou, 1985). Yield reduction by neck blast infection is twice as severe as the leaf blast (Hwang et al., 1987). In India, 75\% loss of grain occurred in 1950 in susceptible cultivars while in the Philippines several thousand hectares suffered causing more than $50 \%$ yield loss $(\mathrm{Ou}, 1985)$.

Use of host resistance provides effective and environmentally safe alternatives against chemical control in disease management. Rice lines resistant to leaf blast at earlier stage were completely resistant to neck blast (Ou, 1985) and those susceptible at the seedling stage were susceptible to neck infection to a particular race of pathogen (Ou and Nuque, 1963). However, Bonaman (1992) reported relationship between leaf and neck blast. Therefore, the purpose of this study was to screen out farmer preferred rice lines against leaf and neck blast and compare relation between leaf and neck blast severity under field condition.

\section{MATERIALS AND METHODS}

The experiment was conducted in farmer's field, i.e. Ratnanagar Municipality and Gitanagar Village Development Committee during July to November 2005 (Figure 1A) on mother trial \{a multi entry participatory varietal selection (PVS) under farmer's level of input and management $\}$. Individual farmer was considered as a block and each rice line as treatment. The site represents the subtropical climatic condition. The weather parameters, i.e. relative humidity, rainfall and solar radiation varied during the study (Figure 1B). The rice lines (Table 1) were evaluated under low-, mid-and up-land situations. The rice lines were replicated 6, 16, 4 times under up-, mid- and low-lands, respectively, using Masuli as susceptible check. 

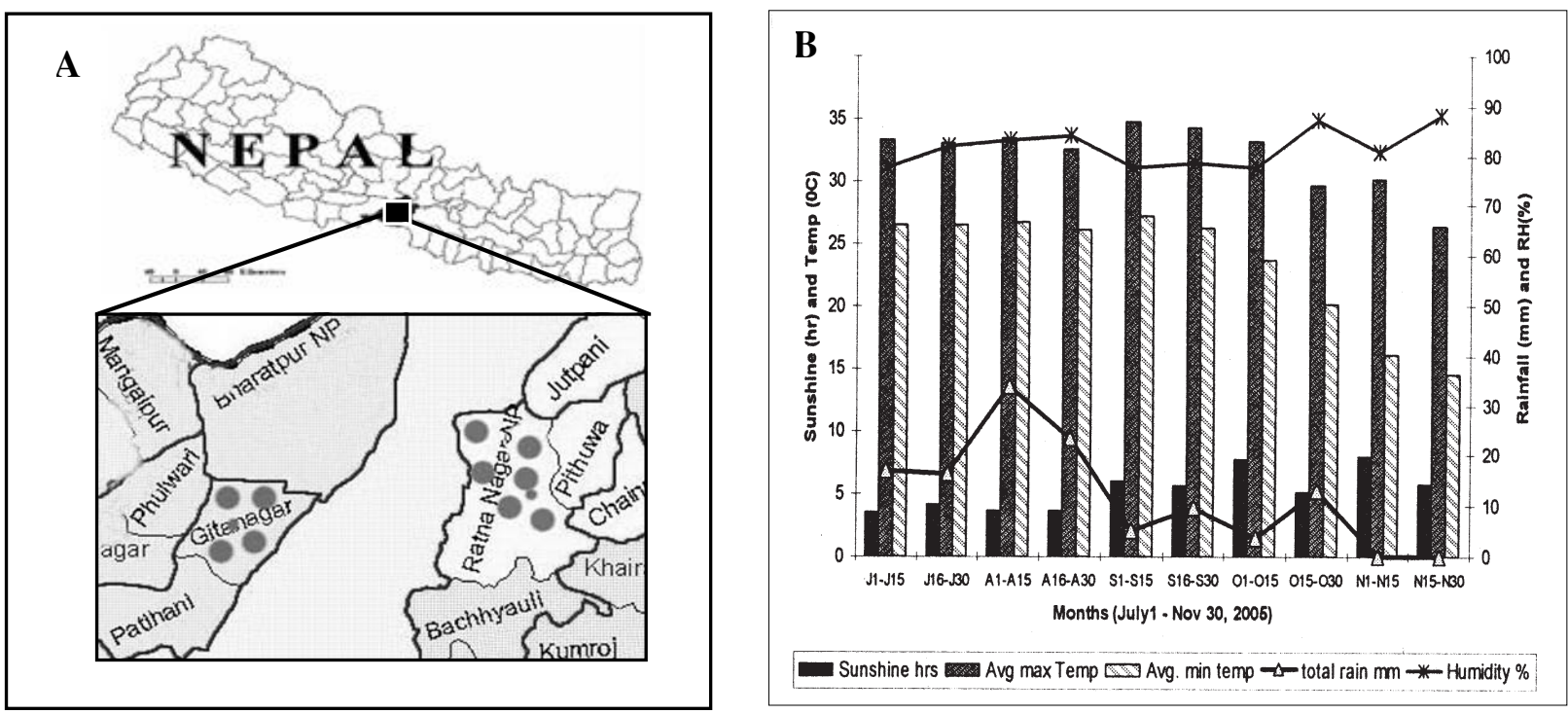

Figure 1. (A) Different locations of field trials on Ratnanagar and Gitanagar, (B) Weather conditions Chitwan during experimental period (July to November 2005). (Source: Meteorological Station of National Maize Research Program, NARC, Rampur, Chitwan)

Table 1. Rice lines used on different land conditions on field of both Ratnanagar and Gitanagar during rainy season, 2005

\begin{tabular}{|llll|}
\hline Upland & Midland & Lowland \\
\hline Barkhe 1006 & Barkhe 2001 & Masuli/MT P \# 109 & Barkhe 3004 \\
Barkhe 1027 & Barkhe 2014 & Masuli/MT P \# 11 & Barkhe 3015 \\
Judi 567 & Barkhe 2024 & Masuli/MT P \# 137 & Barkhe 3017 \\
Judi 572 & Barkhe 2044 & Masuli/MT P \# 140 & Barkhe 3018 \\
Judi 582 & Barkhe 2045 & Masuli/MT P \# 143 & Barkhe 3019 \\
Sugandha 1 & Barkhe 3017* & Masuli/MT P \# 168 & Sugandha 2002 \\
Masuli & Masuli/MT P \# 69 & Masuli/MT P \# 182 & Super 3004 \\
& Masuli/MT P \# 86 & Masuli/MT P \# 193 & Masuli \\
& Masuli & & \\
\hline
\end{tabular}

Barkhe 3017 was used in both midland and lowland condition. [Lowland refers to the irrigated, continuous water-standing plot, mid land refers to the irrigated but not continuously water standing plots and finally upland had not irrigation facilities at all and remains dry when there was not natural rainfall]. The rice lines were developed by CAZS, University of Wales, UK and Local Initiatives for Biodiversity Research and Development (LI-BIRD).

\section{Disease assessments}

Ten plants were randomly (diagonally) selected from each plot $\left(3 \times 2 \mathrm{~m}^{2}\right)$ and tagged. Disease rating was done on the tagged plant at growth stage 2 (Tillering), 4 (Booting), and 8 (Flowering) for leaf blast and 9 (mature grain) for neck blast. In larger plots $\left(3 \times 20 \mathrm{~m}^{2}\right)$, one square meter area was selected from five different spot. The disease severity was calculated as $\{$ Disease severity $\%=$ Sum of all numerical rating/Total no. of leaves or plants observed__ Maximum rating_ 100, (Shrestha and Mishra, 1994)\}. Based on the disease severity, lines with $0-15 \%$ leaf infection were considered as resistant (R), 15.1-30\% infection as moderately resistant (MR), 30.1-50\% infection as moderately susceptible (MS), and 50.1-100\% infection as susceptible. Neck blast scoring was also done as standard evaluation system for rice (SESR) (IRRI, 2002). Based on the plot scoring system lines were classified as: $0-10 \%$ neck infection as resistant (R), $11-25 \%$ infection as moderately resistant (MR), 26-50\% infection as moderately susceptible (MS), and 51-100\% infection as susceptible (S).

\section{Agronomical characters}

Number of days to heading was recorded when $50 \%$ panicles emerged from the tagged plants. Number of days to maturity was determined when the panicle of almost all plants in a plot became gray, golden and 
hard. Plant height was measured from base of the plants to tip of the grains. Ten panicles were selected randomly from each plot for calculating number of grains per spike.

\section{Data analysis}

Disease rating, grain yield and other parameter were analyzed using MSTATC. Area Under Disease Progress Curves (AUDPC) was calculated using the formula used by Das et al. (1992).

\section{RESULTS}

\section{Leaf blast severity in field condition}

Upland rice lines: The highest disease severity was found on Sugandha 1 reaching to maximum at booting stage $(24.3 \%)$ and minimum at tillering stage (15.4\%). The rice lines Judi 567, Judi 572, and Judi 582 got minimum infection, while Barkhe 1006 and Barkhe 1027 had maximum severity at dough stage (Figure 2).

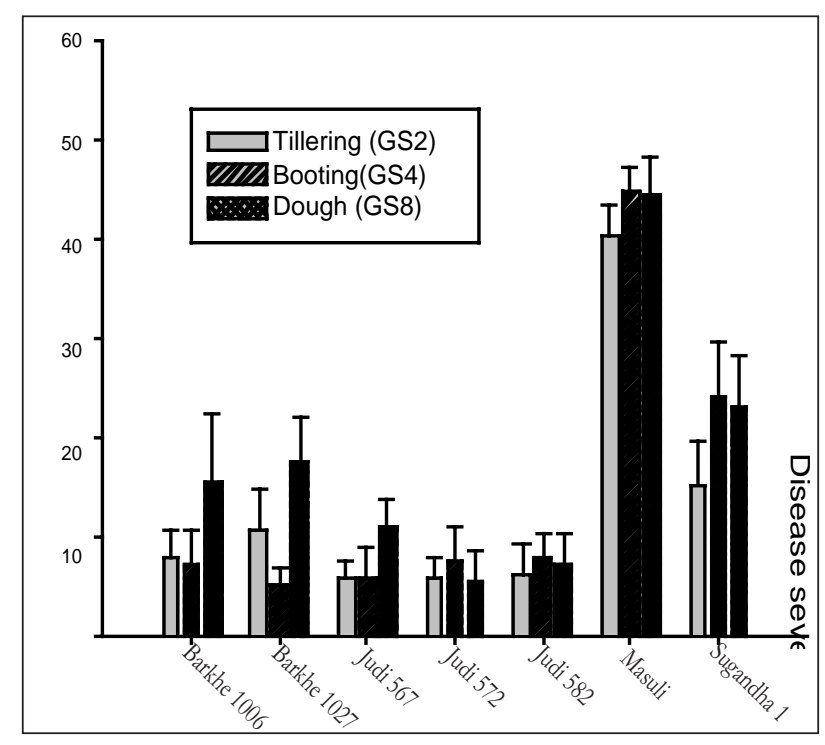

Upland rice genotypes

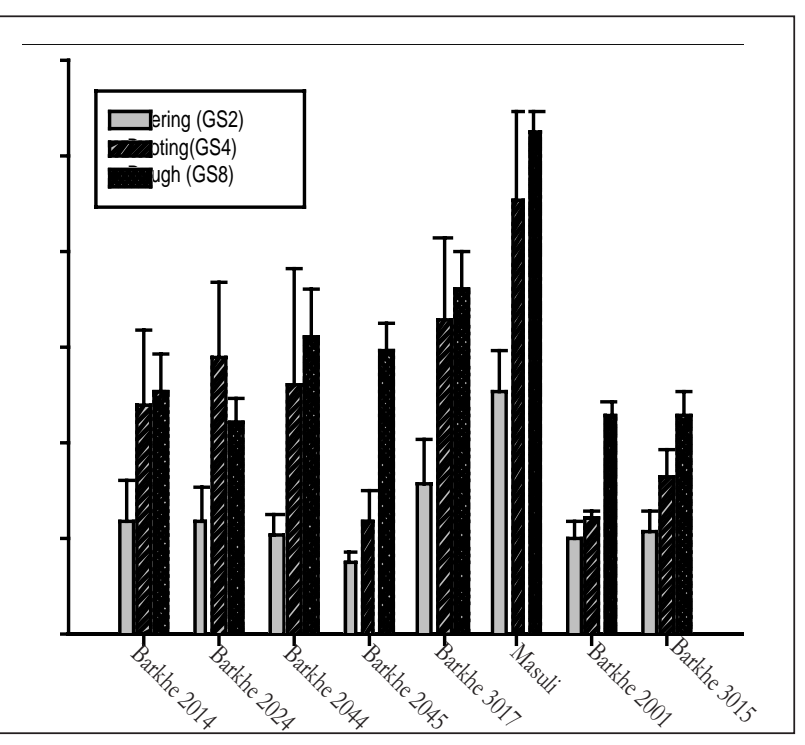

Midland rice genotypes

Fig 2. Leaf blast severity in upland and midland rice lines at different growth stages on farmer's field in Ratnanagar and Gitanagar, 2005

\section{Midland rice lines}

Among Masuli_MT4 rice lines maximum disease severity was recorded on Masuli_MT4 P \# 137 at dough (53.55\%), booting (36.88\%), and tillering (21\%) stages, followed by Masuli_MT4 P \# 140 (53.77\%, 9.11\% and $21.11 \%$ ) at respective growth stages. In other lines, the disease severity varied from 5 to $47 \%$ (Figure 3). While in Barkhe 3017, disease severity was maximum at dough stage (36.2\%), followed by booting and minimum was at tillering stage (15.8\%), which was higher than all lines but lower than Masuli. Barkhe 2001 and Barkhe 3015 got the lowest disease severity ranging 10-22.9\% (Fig 4.9). Barkhe 2014, Barkhe 2024, Barkhe 2044, and Barkhe 2045 had similar disease severity (7.7 to $31.3 \%$ ) (Figure 2 B).

\section{Lowland rice lines}

Maximum disease severity was found on Barkhe 3017 at dough stage $(30.45 \%)$, followed by booting $(29.77 \%)$ and tillering stage $(15.33 \%)$ but it was lower than the Masuli at respective growth stage. In Super 3004, Barkhe 3004, Barkhe 3018 and Sugandha 2002 had lower severity indicating variable level of resistances to blast (Figure 3).

\section{Disease and agronomic trait interaction}

Upland rice lines: In upland lines, Masuli was significantly different and got the highest AUDPC (1538) value. Sugandha 1, which got the second highest AUDPC value after Masuli, was significantly different from Barkhe 1006, Barkhe 1027, Judi 567, and Judi 582. Regarding the yield level of upland lines, Sugandha 1 produced 


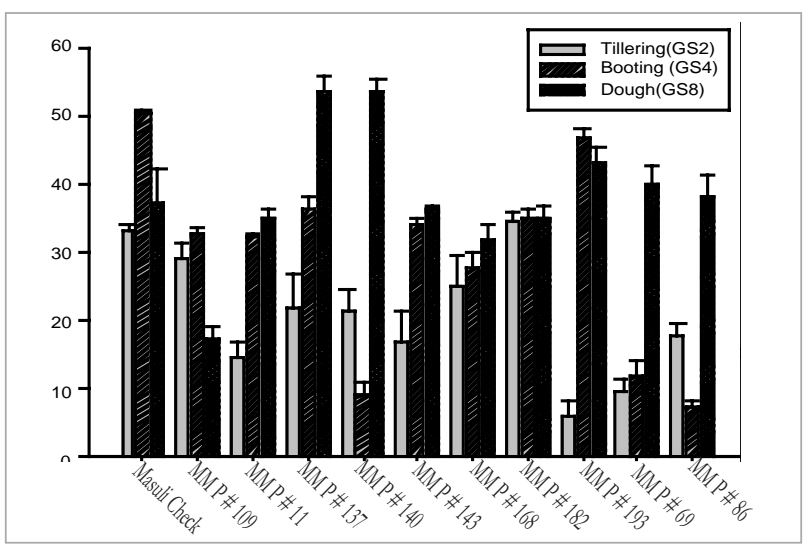

Midland rice lines (Masuli_MT4 line)

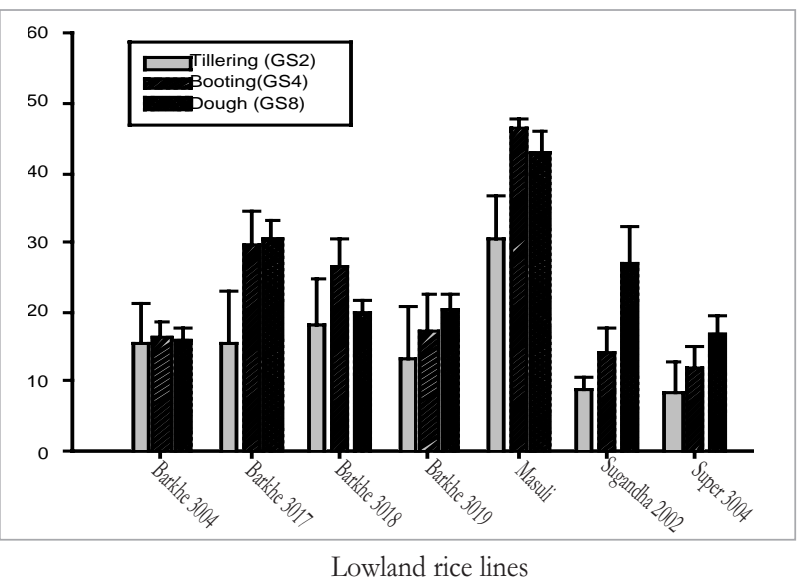

Lowland rice lines

Figure 3. Leaf blast severity in upland and midland rice lines at different growth stages on farmer's field in Ratnanagar and Gitanagar, 2005

the highest yield though it had higher AUDPC value. On yield level, ANOVA was non-significant, however; Sugandha 1 had the highest yield (3.7 ton/ha) followed by Judi 582. Barkhe 1006, Judi 567, Judi 572, and Barkhe 1027 (Table 2). Maturity days and plant height were highly significant, while tiller numbers were significant. In these rice lines total AUDPC value and crop yield were positively correlated $(r=0.25)$.

Table 2. Mean AUDPC value, grain yield (ton/ha), tiller number, plant height $(\mathrm{cm})$ and maturity days of upland lines on farmer field condition in 2005

\begin{tabular}{|c|c|c|c|c|c|}
\hline Line & AUDPC & Grain yield & Tiller number & Plant height & Maturity days \\
\hline Barkhe 1006 & $398.6^{c}$ & $2.7^{\mathrm{b}}$ & $8^{\mathrm{ab}}$ & $102.2^{\mathrm{b}}$ & $124^{\mathrm{b}}$ \\
\hline Barkhe1027 & $355.1^{\mathrm{c}}$ & $3.3^{\mathrm{ab}}$ & $8^{\mathrm{ab}}$ & $92.4^{\mathrm{b}}$ & $111.7^{c}$ \\
\hline Judi 567 & $301.9 \mathrm{c}$ & $2.9^{\mathrm{ab}}$ & $8^{\mathrm{ab}}$ & $93.1^{\mathrm{b}}$ & $117.0^{c}$ \\
\hline Judi 572 & $259.3 \mathrm{c}$ & $2.9^{\mathrm{ab}}$ & $8^{\mathrm{ab}}$ & $102.4^{\mathrm{b}}$ & $116.0^{c}$ \\
\hline Judi 582 & $314.4 \mathrm{c}$ & $3.7^{\mathrm{a}}$ & $9^{\mathrm{a}}$ & $97.5^{\mathrm{b}}$ & $114.2^{\mathrm{c}}$ \\
\hline Masuli & $1538 a$ & $3.3^{\mathrm{ab}}$ & $7^{c}$ & $121.1^{\mathrm{a}}$ & $137.3^{\mathrm{a}}$ \\
\hline Sugandha 1 & $791.7^{\mathrm{b}}$ & $3.7^{\mathrm{a}}$ & $7 b^{c}$ & $131.5^{\mathrm{a}}$ & $111.5^{c}$ \\
\hline $\mathrm{LSD}_{0.05}$ & 192.9 & 0.9 & 1.3 & 10.6 & 6.4 \\
\hline SEm & 66.8 & 0.3 & 0.4 & 3.7 & 2.3 \\
\hline $\mathrm{CV} \%$ & 28.9 & 21.3 & 13.6 & 8.5 & 4.6 \\
\hline Significance & $* *$ & ns & $*$ & $* *$ & $* *$ \\
\hline
\end{tabular}

*Significant at 5\% level, ** significant at $1 \%$ level, ns = non-significant. In column, means followed by the same letter were not significantly different at $5 \%$ level according to DMRT

Table 3. Mean AUDPC value, grain yield (ton/ha), tiller number, plant height $(\mathrm{cm})$ and maturity days of midland lines on farmers field condition in 2005

\begin{tabular}{|c|c|c|c|c|c|}
\hline Line & AUDPC & Grain yield & Tiller number & Maturity days & Plant height \\
\hline Barkhe 2014 & $660.3^{\mathrm{cd}}$ & $3.9^{\mathrm{ab}}$ & $7.7^{\mathrm{ab}}$ & $145.2^{\mathrm{ab}}$ & $119.1^{\mathrm{c}}$ \\
\hline Barkhe 2024 & $722.8^{\mathrm{bc}}$ & $4.5^{\mathrm{a}}$ & $8.5^{\mathrm{a}}$ & $144.4^{\mathrm{ab}}$ & $103.3^{d}$ \\
\hline Barkhe 2044 & $724.1^{b c}$ & $3.7^{\mathrm{ab}}$ & $6.8^{\mathrm{b}}$ & $140.8^{\mathrm{bc}}$ & $96.6^{\mathrm{e}}$ \\
\hline Barkhe 2045 & $459.4^{\mathrm{d}}$ & $3.6^{b}$ & $6.4^{\mathrm{b}}$ & $137.0^{\mathrm{c}}$ & $135.7^{\mathrm{a}}$ \\
\hline Barkhe 3017 & $911.6^{\mathrm{b}}$ & $3.9^{\mathrm{ab}}$ & $6.6^{\mathrm{b}}$ & $140.2^{\mathrm{bc}}$ & $122.2^{\mathrm{bc}}$ \\
\hline Masuli & $1313^{a}$ & $4.4^{\mathrm{ab}}$ & $6.8^{\mathrm{b}}$ & $148.4^{\mathrm{a}}$ & 125.3 \\
\hline $\mathrm{LSD}_{0.05}$ & 210.2 & 0.8 & 1.6 & 5.6 & 4.9 \\
\hline SEm & 71.2 & 0.3 & 0.5 & 1.9 & 1.9 \\
\hline CV\% & 19.9 & 15.49 & 17.1 & 2.9 & 3.2 \\
\hline Significance & $* *$ & ns & ns & $* *$ & $* *$ \\
\hline
\end{tabular}

*Significant at $5 \%$ level, ** significant at $1 \%$ level, ns $=$ non-significant. In a column, means followed by the same letter were not significantly different at $5 \%$ level according to DMRT 


\section{Midland rice lines}

AUDPC on Masuli was significantly different and the highest among all of the lines. Disease progress of Barkhe 3017 was significantly higher than that of Barkhe 2014 and Barkhe 2045 but similar to that of Barkhe 2024 and Barkhe 2044. AUDPC in Barkhe 2045 was significantly lower than all lines but similar with Barkhe 2014. Barkhe 2024 (4.5 t/ha) showed the maximum yield, while Barkhe 2045 produced the lowest (3.5 t/ha) but consistent yield with other (Table 3$)$. Plant height and maturity days were highly significant $(\mathrm{p} \leq 0.01)$ among all the lines but tiller number showed non-significant relation.

In Masuli_MT4 parentage, disease progress was significant. Maximum disease progress recorded in Masuli was at par with Masuli_MT $\mathrm{P}$ \# 137. Minimum progress was in Masuli_MT 4 P \# 69 and Masuli_MT 4 P \# 86. While Masuli_MT 4 P \# 140, Masuli_MT P P 168 and Masuli_MT 4 P \# 143 exhibited similar level of disease progress in field condition (Table 4).

Table 4. Mean AUDPC value on midland lines at farmers field condition, 2005

\begin{tabular}{|c|c|c|c|}
\hline Rice lines & AUDPC value & Rice lines & AUDPC value \\
\hline Masuli (SC) & $40.07^{\mathrm{a}}$ & Masuli_MT $_{4}$ P \# 168 & 27.9de \\
\hline Masuli_MT 4 P \# 109 & $26.2^{\mathrm{e}}$ & Masuli_MT 4 P \# 182 & $34.5 b c$ \\
\hline Masuli_MT 4 P \# 11 & $26.9^{\mathrm{e}}$ & Masuli_MT 4 P \# 193 & $31.3 \mathrm{~cd}$ \\
\hline Masuli_MT $_{4}$ P \# 137 & $37.6^{\mathrm{ab}}$ & Masuli_MT 4 P \# 69 & $20.07 \mathrm{f}$ \\
\hline Masuli_MT 4 P \# 140 & $28.0 \mathrm{~d}^{\mathrm{e}}$ & Masuli_MT 4 P \# 86 & $21.6 \mathrm{f}$ \\
\hline Masuli_MT 4 P \# 143 & $28.9 \mathrm{~d}^{\mathrm{e}}$ & & \\
\hline $\mathrm{LSD}_{0.05}$ & 3.662 & & \\
\hline SEm & 1.281 & & \\
\hline CV\% & 9.75 & & \\
\hline Significance & ** & & \\
\hline
\end{tabular}

** Significant at $1 \%$ level, in a column means followed by the same letter were not significantly different at $5 \%$ level according to DMRT

\section{Lowland rice lines}

Among the lowland lines, the highest and significant disease progress was recorded. Masuli had the highest and significantly higher AUDPC as compared to all of other lines but Barkhe 3017 followed it. However, AUDPC was statistically similar with Barkhe 3018, whereas Super 3004 and Barkhe 3019 exhibited the lowest AUDPC value (Table 5). Analysis of variance showed the non-significant difference to yield but Barkhe 3019 (4.57 t/ha) was the highest yielder and at par with Barkhe 3004, Barkhe 3018, Masuli, Sugandha 2002, and Super 3004 (Table. 5). In lowland rice lines, yield and AUDPC value were negatively correlated $\left(r^{2}=-0.3\right)$. Tiller numbers were non-significant whereas plant height and maturity days were significant $(\mathrm{p} \leq 0.05)$.

\section{Neck blast infection in field condition}

\section{Upland condition}

Judi 567, Judi 572, Judi 582 and Barkhe 1006 were resistant to neck blast. Sugandha 1 and Barkhe 1027 were moderately resistant while Masuli was susceptible to it (Table 6).

\section{Midland condition}

Masuli_MT P P 86 and Masuli_MT 4 P \# 140 were resistant to neck infection. Barkhe 2014, Barkhe 2024, Barkhe 2001 and most of Masuli_MT 4 lines showed moderately resistant reaction (Table 6).

\section{Low land condition}

In lowland, the rice lines Barkhe 3015, Barkhe 3018, and Barkhe 3019 were resistant. Barkhe 3004, Super 3004, and Sugandha 2002 were moderately resistant, while Barkhe 3017 and Masuli were susceptible.

\section{Comparison between leaf and panicle blast}

In field evaluation, Barkhe 1006, Judi 567, Judi 572, and Judi 582 were found resistant to both leaf and neck blast. While, Barkhe 1027, Barkhe 2001, Barkhe 2014, Barkhe 2024, Sugandha 1 and Sugandha 2002 were found moderately resistant to both leaf and neck panicle blast. 
Table 5. Mean AUDPC value, grain yield (ton/ha), tiller number, plant height $(\mathrm{cm})$ and maturity days of lowland rice lines on farmers field condition in 2005

\begin{tabular}{|c|c|c|c|c|c|}
\hline Lines & AUDPC & Grain yield & Tiller number & Plant height & Maturity days \\
\hline Barkhe 3004 & $412.5^{\mathrm{cd}}$ & $3.9^{\mathrm{ab}}$ & $8.9^{\mathrm{a}}$ & $99.0^{\mathrm{c}}$ & $148.8^{a}$ \\
\hline Barkhe 3017 & $697.1^{\mathrm{b}}$ & $2.2^{\mathrm{b}}$ & $8.3^{\mathrm{a}}$ & $127.3^{\mathrm{a}}$ & $139.3^{\mathrm{b}}$ \\
\hline Barkhe 3018 & $611.9^{b c}$ & $3.2^{\mathrm{ab}}$ & $7.5^{\mathrm{a}}$ & $111.1^{\mathrm{a}-\mathrm{c}}$ & $143.3^{\mathrm{ab}}$ \\
\hline Barkhe 3019 & $348.6^{\mathrm{d}}$ & $4.6^{\mathrm{a}}$ & $8.4^{\mathrm{a}}$ & $106.5^{\mathrm{c}}$ & $149.0^{\mathrm{a}}$ \\
\hline Masuli & $1080^{\mathrm{a}}$ & $3.7^{\mathrm{ab}}$ & $7.0^{\mathrm{a}}$ & $125.6^{\mathrm{ab}}$ & $149.3^{\mathrm{a}}$ \\
\hline Sugandha 2002 & $400.7^{\mathrm{cd}}$ & $3.8^{\mathrm{ab}}$ & $9.1^{\mathrm{a}}$ & $108.1^{b c}$ & $147.5^{\mathrm{a}}$ \\
\hline Super 3004 & $312.5^{\mathrm{d}}$ & $3.5^{\mathrm{ab}}$ & $6.9^{\mathrm{a}}$ & $114.6^{\mathrm{a}-\mathrm{c}}$ & $147.8^{a}$ \\
\hline SEm & 72.8 & 0.53 & 1.0 & 5.5 & 2.6 \\
\hline $\mathrm{CV}^{0} \%$ & 26.4 & 29.4 & 25.9 & 9.6 & 3.6 \\
\hline $\mathrm{LSD}_{0.05}$ & 216.5 & 1.6 & 3.1 & 16.2 & 7.8 \\
\hline Significance & ** & ns & ns & $*$ & $*$ \\
\hline
\end{tabular}

*Significant at $5 \%$ level, $* *$ significant at $1 \%$ level, ns $=$ non significant. In a column means followed by the same letter were not significantly different at $5 \%$ level according to DMRT

Table 6. Reaction of rice lines to leaf blast severity and panicle blast under field at Gitanagar and Ratnanagar, Chitwan during main season of 2005

\begin{tabular}{|c|c|c|c|c|}
\hline Line & Maximum disease severity $\%$ & Reaction & Neck blast $\dagger$ & Reaction \\
\hline Barkhe 1006 & 15.7 & $\mathrm{R}$ & 1.8 & $\mathrm{R}$ \\
\hline Barkhe 1027 & 17.9 & MR & 3.0 & MR \\
\hline Barkhe 2001 & 22.9 & MR & 3.1 & MR \\
\hline Barkhe 2014 & 25.3 & MR & 2.2 & MR \\
\hline Barkhe 2024 & 29. & MR & 2.2 & MR \\
\hline Barkhe 2044 & 31.3 & MS & 4.2 & MS \\
\hline Barkhe 2045 & 29.8 & MS & 4.6 & MS \\
\hline Barkhe 3004 & 16.2 & MR & 2.5 & MR \\
\hline Barkhe 3015 & 35.9 & MS & 0.0 & $\mathrm{R}$ \\
\hline Barkhe 3017 & 36.2 & MS & 4.2 & MS \\
\hline Barkhe 3018 & 26.7 & MR & 2.0 & $\mathrm{R}$ \\
\hline Barkhe 3019 & 20.4 & MR & 2.0 & $\mathrm{R}$ \\
\hline Judi 567 & 10.4 & $\mathrm{R}$ & 1.0 & $\mathrm{R}$ \\
\hline Judi 572 & 7.8 & $\mathrm{R}$ & 1.7 & $\mathrm{R}$ \\
\hline Judi 582 & 7.6 & $\mathrm{R}$ & 1.7 & $\mathrm{R}$ \\
\hline Masuli & 52.67 & $\mathrm{~S}$ & 7.5 & S \\
\hline Masuli_MT4 P \# 11 & 34.9 & MS & 3.4 & MR \\
\hline Masuli_MT4 P \# 137 & 53.6 & $\mathrm{~S}$ & 5.1 & MS \\
\hline Masuli_MT4 P \# 140 & 53.8 & S & 1.8 & $\mathrm{R}$ \\
\hline Masuli_MT4 P \# 143 & 36.1 & MS & 3.5 & MR \\
\hline Masuli_MT4 P \# 168 & 31.9 & MS & 4.2 & MS \\
\hline Masuli_MT4 P \# 182 & 34.9 & MS & 3.2 & MR \\
\hline Masuli_MT4 P \# 193 & 46.9 & MS & 5.6 & MS \\
\hline Masuli_MT4 P \#69 & 39.8 & MS & 3.7 & MR \\
\hline Masuli_MT4 P \# 86 & 38.2 & MS & 1.6 & $\mathrm{R}$ \\
\hline Masuli_MT4 P \# 109 & 32.7 & MS & 3.5 & MR \\
\hline Sugandha 1 & 24.3 & MR & 2.8 & MR \\
\hline Sugandha 2002 & 27.1 & MR & 3.0 & MR \\
\hline Super 3004 & 16.7 & $\mathrm{R}$ & 2.5 & MR \\
\hline
\end{tabular}

tplot score of neck blast incidence and severity were recorded using IRRI standard 


\section{DISCUSSION}

The different progenies from various crosses showed the different level of blast disease reaction. Such differential defense responses result from the interaction of dominant and resistant (R) gene of host and avirulence (AVR) genes of pathogen as proposed gene-for-gene hypothesis (Flor, 1971). In rice, interaction between host plant and pathogen M. grisea is well documented as gene-for-gene system (Silue et al., 1992). Jia et al. (2000) reported that resistance and susceptible interaction on rice conferred by single amino acid substitution in Pi-ta leucine rich domain (LRD) or in the AVR-Pi-ta $a_{176}$ protease motif that result in loss of resistant in plant and also disturb the physical interaction among them. Thus, the different genetic background of rice lines used in this study showed different interaction to leaf as well as neck blast. Such result also supported by the work of Koh et al. (1987) and Chaudhary (2001).

Area under disease progress curve (AUDPC) differed along with rice lines and varied level of yield was reported in different rice lines. Rice lines Barkhe 1034, Judi 582, and Barkhe 1036 from upland, Masuli_MT4 P \# 11 from midland lines and Barkhe 3017 from lowland lines had the highest infection. Disthaporn (1994) reported 60\% panicle blast during 1992 due to neck blast. Chin (1974) reported the losses up to $70 \%$ in fields due to neck blast. Bonman et al. (1991) also reported 16.25\% incidence of neck blast on cultivar Bonggwang.

Disease severity varied according to the rice lines. Disease severity was higher on the dough stage followed by booting and late tillering stage. Under tropical low land condition, blast is damaging (Bonman et al., 1989). Thus, the upland dry seedbed was more favorable in blast development at seedling stage (Thruston, 1998). Soil moisture plays important role in disease development than humidity of the air (Thruston, 1998). Bonman and Mackill (1988) and Gill and Bonman (1988) mentioned water stress increase lesion size and disease severity. Extended dew periods and frequent moisture stress in upland rice increased disease incidence and continued increase in blast populations on leaves beyond maximum tillering (Ou, 1985; Gill and Bonman, 1988). In contrast to this, under favorable weather conditions severe blast epidemics of blast on flooded rice also reported (Disthaporn, 1994). Diseases also prevalent when plants predisposed by high inputs particularly nitrogenous fertilizer, low silicon level and low night temperatures (Kim, 1994). Thus, due to different genetic background, crop situation, prevailing environmental condition, host nutrition difference etc. might be responsible for the disease development. The adverse environmental conditions i.e. very low rainfall and relative humidity during July/August checked disease development at earlier stage and optimum rainfall and sufficient humidity at late growth stage cause higher disease infection.

\section{CONCLUSIONS}

Rice blast caused by Pyricularia grisea Sacc. is one of the most destructive and cosmopolitan disease with great potential threat for successful rice production. Among 30 rice lines evaluated on farmers field condition, Masuli_MT4P, 5 were resistant, 10 moderately resistant, 12 moderately susceptible and 3 were susceptible to leaf blast. For the neck blast, 9 lines were resistant, 13 moderately resistant 7 moderately susceptible and 1 was susceptible. Barkhe 1006, Judi 567, Judi 572, Judi 582, Super 3004 were resistant to leaf infection but Masuli, Masuli_MT4 P \# 137 and Masuli_MT4 P \# 140 were susceptible. Similarly, for neck blast, Barkhe 1006, Barkhe 3015, Barkhe 3018, Barkhe 3019, Judi 567, Judi 572, Judi 582, Masuli_MT4 P \# 140, and Masuli_MT4 P \# 86 were resistant. The most of Masuli_MT4 lines showed susceptible reaction to both leaf and neck blast while progenies from the parentage IPB (Irradiated Pusa Basmati), KIII_IR64 (KalinghaIII_IR64) and Masuli_IR64 were found most promising resistant sources against rice blast. Thus, the progenies from these parents must be upgraded, further tested on farmers field trial as well as in green house and released as resistant variety.

\section{AVKNOWLEDGEMENT}

The authors are highly thankful to DFID, Plant Science Research Programme (PSRP), UK, LI-BIRD, and to Directorate of Research, IAAS Rampur, Nepal for the financial support to this study. 


\section{REFERENCES CITED}

Bonman, J. M. 1992. Durable resistance to rice blast environmental influences. Euphytica 63:115 -123.

Bonman, J. M. and D. J. Mackill. 1988. Durable resistance to rice blast disease. Oryza 25: 103-110.

Bonman, J. M., B. A. Estrada and J. M. Bandong. 1989. Leaf and neck blast resistance in tropical lowland rice cultivars. Plant Disease 73:388-390.

Bonman, J. M., B. A. Estrada, C.K. Kim, D.S. Ra, and E.J. Lee. 1991. Assessment of blast disease and yield loss in susceptible and partially resistant rice cultivars in two irrigated low land environments. Plant Disease 75:462-466.

Chaudhary, B., B. P. Karki and K. K. Lal. 1994. Neck blast resistant lines of Radha-17 isolated. Intl. Rice Res. Notes 19:11.

Chaudhary, B. 2001. Rice blast: Pathogenic variability and host resistance. M.Sc. Thesis, Tribhuvan University, Institute of Agriculture and Animal Sciences, Rampur, Chitwan, Nepal.

Chin, K. M. 1974. Collar rot, a new symptom of the rice blast disease. MARDI Res. Bull. 2:82-84.

Das, M. K., S. Rajaram, C. C. Mundt, W.E. Kronstad. 1992. Inheritance of slow rusting resistance to leaf rust in wheat. Crop Sci. 32:1452-1456.

Disthaporn, S. 1994. Current rice blast epidemics and their management in Thailand. In: R. S. Zeigler, S. A. Leong, and P. S. Teng. (eds.) Rice blast disease. CAB International, Wallingford, UK, in association with IRRI, Manila, Philippines. pp. 333-342.

Flor, H. H. 1971. Current status of the gene-for-gene concept. Ann. Rev. Phytopath. 9:275-296.

Gill, M. and J. M. Bonman. 1988. Effects of water deficit on rice blast. I. Influence of water deficit on components of resistance. J. Plant Prot. Tropics 5:61-66.

Hwang, B. K., Y. J. Koh and H.S. Chung. 1987. Effects of adult-plant resistance on blast severity and yield of rice. Plant Disease 71:1035-1038.

IRRI. 2002. Standard evaluation system for rice. International Rice Research Institute, Los Banos, Manila, Philippines.

Jia, Y., S. A. McAdams, G. T. Bryan, H. P. Hershey and B. Valen. 2000. Direct interaction of resistant genes and avirulence gene products confers rice blast resistant. The EMBO J. 19: 4004-4014.

Kim, C. K. 1994. Blast management in high input, high yield potential temperate rice ecosystems. In: R. S. Zeigler, S. A Leong., P. S Teng. (eds.) Rice Blast Disease. CAB International, Wallingford, UK, in association with IRRI, Manila, Philippines. pp. 451-464.

Koh, Y. J., B. K. Hwang and H. S. Chung. 1987. Adult plant resistant to rice blast. Phytopath. 77:232-236.

Manandhar, H. K., K. Shrestha and P. Amatya. 1992. Seed-borne diseases. In: S. B. Mathur, P. Amatya, K. Shrestha, and H. K. Manandhar (eds.) Plant Diseases, Seed Production and Seed Health Testing in Nepal. Danish Government, Institute of Seed Pathology for Developing Countries, Copenhagen, Denmark. pp. 59-74.

Ou, S. H. ( $2^{\text {nd }}$ ed.). 1985. Rice diseases. Common Wealth Mycological Institute. Kew, Surrey, England.

Ou, S. H. and F. L. Nuque. 1963. The relation between leaf and neck blast resistant to the rice blast disease. Int. Rice Comn. Newsl. 12:30-34.

Shrestha, S. M. and N. K. Misra. 1994. Evaluation of common cultivars of rice against leaf and neck blast in Nepal. J. Inst. Agric. Anim. Sci. 15:101-103.

Silue, D., J. L. Notteghem, and D. Tharreau. 1992. Evidence for the gene for gene relationship in the Oryza sativa-Magnaporthe grisea pathosystem. Phytopath. 82:577-580.

Teng, P. S., H. Klein-Gebbinck, H. Pinnschmidt. 1991. An analysis of the blast pathosystem to guide modeling and forecasting. In: Blast Modeling and Forecasting. IRRI, Manila, Philippines. pp. 1-30.

Thruston. H. D. ( $2^{\text {nd }}$ ed.). 1998. Tropical plant diseases. APS Press. American Phytopath. Soc. pp. 31-40.

Yeh, W. H. and J. M. Bonman. 1986. Assessment of partial resistance to Pyricularia oryzae in six rice cultivars. Plant Path. 35:319-323. 